\title{
Mapping of cisterns and water quality analysis at the Nova Assunção settlement in Aracoiaba, Ceará.
}

\author{
Mapeamento das cisternas e análise da qualidade da água no assentamento \\ Nova Assunção em Aracoiaba, Ceará.
}

\author{
Antônio Patrick Meneses de Brito' \\ Manuel Pereira de Sousa" \\ Luzia Luziene de Castro Aguiar"' \\ Olienaide Ribeiro de Oliveira Pinto ${ }^{\text {IV }}$ \\ Ciro de Miranda Pintov \\ Maria Gorete Flores Salles ${ }^{\mathrm{V}}$
}

\begin{abstract}
The objective of the work was to map the cisterns of the Novo Assunção settlement in Aracoiaba and analyze their water quality, using descriptive statistics and multivariate statistics through grouping analysis and main component analysis. The geographical location of each cistern was obtained by the Global Positioning System (GPS), model Garmim 76scx. A semi-structured questionnaire on water use and handling in cisterns was applied in the study area. Six physical-chemical parameters, temperature, turbidity, hydrogen ion potential $(\mathrm{pH})$, total dissolved solids (STD), electrical conductivity (EC) and apparent color were evaluated in the water by descriptive statistics and multivariate analysis. Seventeen cisterns were mapped, of which $100 \%$ are used for human consumption, of which $76.5 \%$ had no protective screen. In the water analysis, inadequacy was observed for the parameters apparent color, EC, turbidity and $\mathrm{pH}$. In four cisterns there was $50 \%$ irregularity in the attributes. Thus, the mapped cisterns are an indispensable alternative for the storage and guarantee of water in the settled

'Graduando em Agronomia na Universidade da Integração Internacional da lusofonia Afro-brasileira (UNILAB), Redenção, CE, Brasil - patrickmeneses675@gmail.com

"Graduando em Agronomia pela Universidade da Integração Internacional da Lusofonia Afro-Brasileira (UNILAB), Redenção, CE, Brasil - manuelsousa@aluno.unilab.edu.br

"'Graduanda em Agronomia na Universidade da Integração Internacional da Lusofonia Afro-Brasileira (UNILAB), Redenção, CE, Brasil - luziacastroo@yahoo.com.br

IVPós-Doutorado vinculado ao Mestrado Acadêmico em Sociobiodiversidade e Tecnologias Sustentáveis (MASTS) na Universidade da Integração Internacional da Lusofonia Afro-Brasileira (UNILAB), Redenção, CE, Brasil - agron.olienaide@gmail.com

$\checkmark$ Professor Adjunto IV da Universidade da Integração Internacional da Lusofonia Afro-Brasileira (UNILAB), Redenção, CE, Brasil - ciroagron@unilab.edu.br

VIProfessora Adjunta IV no curso de Agronomia do Instituto de Desenvolvimento Rural, da Universidade da Integração Internacional da Lusofonia Afro-Brasileira (UNILAB), Redenção, CE, Brasil - gorete@unilab.edu.br
\end{abstract}


community, however, some hygiene measures are necessary to improve the use, since the highest destination of water corresponds to human consumption followed by domestic use.

Keywords: enzymatic extract, bromelain, pineapple, fatty acids, transesterification.

\section{Resumo}

O trabalho teve como objetivo mapear as cisternas do assentamento Novo Assunção em Aracoiaba e analisar a qualidade da água dessas, com uso da estatística descritiva e da estatística multivariada através da análise de agrupamento e análise de componente principal. A localização geográfica de cada cisterna foi obtida pelo Sistema de Posicionamento Global (GPS), modelo Garmim 76scx. Aplicou-se na área de estudo um questionário semiestruturado sobre o uso da água e formas de manipulação nas cisternas. Avaliou-se na água seis parâmetros físico-químicos, temperatura, turbidez, potencial hidrogeniônico $(\mathrm{pH})$, sólidos totais dissolvidos (STD), condutividade elétrica (CE) e cor aparente pela estatística descritiva e análise estatística multivariada. Foram mapeadas 17 cisternas, destas, $100 \%$ são utilizadas para consumo humano, das quais $76,5 \%$ não tinham tela de proteção. Nas análises da água foram observadas inadequação para os parâmetros cor aparente, CE, turbidez e pH. Em quatro cisternas houve $50 \%$ de irregularidade nos atributos. Assim, as cisternas mapeadas são uma alternativa imprescindível para o armazenamento e a garantia da água na comunidade assentada, no entanto, são necessárias algumas medidas de higiene para a melhoria do uso, já que o maior destino da água corresponde ao consumo humano seguido do uso doméstico.

Palavras-chave: Energia renovável. Transesterificação. Jatropha gossypifolia L. Caracterização físico-química. 


\section{Introduction}

In Brazil, the semi-arid northeast is a region that is characterized by low rainfall, irregular rainfall distribution throughout the year and high temperatures. In addition to leading extreme events of drought (MARENGO, 2006). These characteristics are factors that contribute to the frequent water scarcity that generates losses to the families in the question of production and survival.

This climatic condition has always occurred as part of the semi-arid characteristic. To the detriment of this fact, survival strategies have always been sought with this reality, among them social technologies, which present low costs for implementation and handling. Through this scenario, some of these technologies have the function of providing better conditions for capturing and storing water, one of the most essential resources for human development, and scarce in these regions.

One of the main initiatives to provide access to water for families living in the semiarid region, came through the Articulation of the Brazilian Semiarid (ASA), which created in 2000, the "Program of Formation and Social Mobilization for Coexistence with the Semiarid: One Million Rural Cisterns - P1MC". The main objective of the program was the construction of one million rural cisterns, intended to benefit approximately five million families living with the problem of water scarcity in the semi-arid region of Northeast Brazil (SILVA, 2006).

These technologies are used to collect and store rainwater in the rainy season, so that families have water in the dry season. According to Tavares (2009) rainwater, harvesting using homemade cisterns has proven to be an adequate option to make water available for human consumption in these regions with low and irregular rainfall, as they adapt well to the soil and climate, socioeconomic and cultural conditions of the region.

The importance of these water management technologies has guaranteed rural producers better quality of life and well-being, thus access to and enhancement of the resource results in an understanding of water scarcity and consequently develops sustainable and reciprocal coexistence practices with problems associated with water scarcity (CONTI; SCHROEDER, 2013). With so many benefits provided by these technologies, some considerations must be observed, such as the quality of the water stored and the ways 
in which the cisterns are used. Some studies point out irregularities in the water potability patterns of rural cisterns, which are often associated with incorrect use of their consumers (LORDELO; PORSANI; BORJA, 2018; SILVA et al., 2014).

The quality of water in cisterns can be affected by some factors such as dust, dirt, animal feces and leaves, which can generate undesirable odors and flavors for it because the greater the risk of contamination, the greater must be the rigor in the sanitary protection of cisterns (PALHARES, 2016).

The joint evaluation of Physico-chemical attributes to check water quality is possible with the use of multivariate statistics through cluster analysis techniques and principal component analysis. The main component analysis to assess water quality was used by Girão et al. (2007) and Souza et al. (2013). As grouping analysis, involving water quality attributes, they were researched by Palácio et al. (2009) and Salgado et al. (2011).

Therefore, this work aimed to map the cisterns of the Novo Assunção settlement in Aracoiaba and analyze their water quality, using descriptive statistics and multivariate statistics through grouping analysis and main component analysis.

\section{Material and Methods}

\section{Location and characterization of the study area}

The municipality of Aracoiaba is located in the Northeast region of Brazil, in the state of Ceará, specifically in the region that corresponds to the territory of the Baturité Massif, at $4^{\circ} 22^{\prime} 16^{\prime \prime}$ south latitude and $38^{\circ} 48^{\prime} 51^{\prime \prime}$ west longitudes. The climate is characterized in Tropical Warm Semi-arid, Tropical Warm Semi-arid Brandy and Tropical Warm Sub-humid, with temperatures ranging from $24^{\circ}$ to $26^{\circ} \mathrm{C}$. The rainy period corresponds to the months of February to April, with average precipitation of $1,010 \mathrm{~mm}$. The relief is made up of sertanejas depressions and residual massifs, where the main classified soils are Quartz Sands, RedYellow Podzolic, Alluvial Soils, Litholic Soils and Solodic Planosolo. The vegetation is composed of Subcaducifolic Rain Forest and Dense Arbustive Caatinga (IPECE, 2017).

The study was developed in the federal settlement Nova Assunção, located in the municipality of Aracoiaba, Ceará. The settlement is divided into two localities, Pedra Aguda 
and Asunción, the total territorial extension is 737.43 ha (Figure 1). The portion comprising the Acute Stone is geographically located between coordinates $4^{\circ} 41^{\prime} 90^{\prime \prime}$ South latitude and $38^{\circ} 76^{\prime} 92^{\prime \prime}$ West longitude, with an altitude of $88 \mathrm{~m}$, the community of Asunción is at $4^{\circ} 25^{\prime \prime}$ South latitude and $38^{\circ} 46^{\prime \prime}$ West longitude, with an altitude of $73 \mathrm{~m}$ (MAIA et al., 2019).

Figure 1 - Location map of the study area

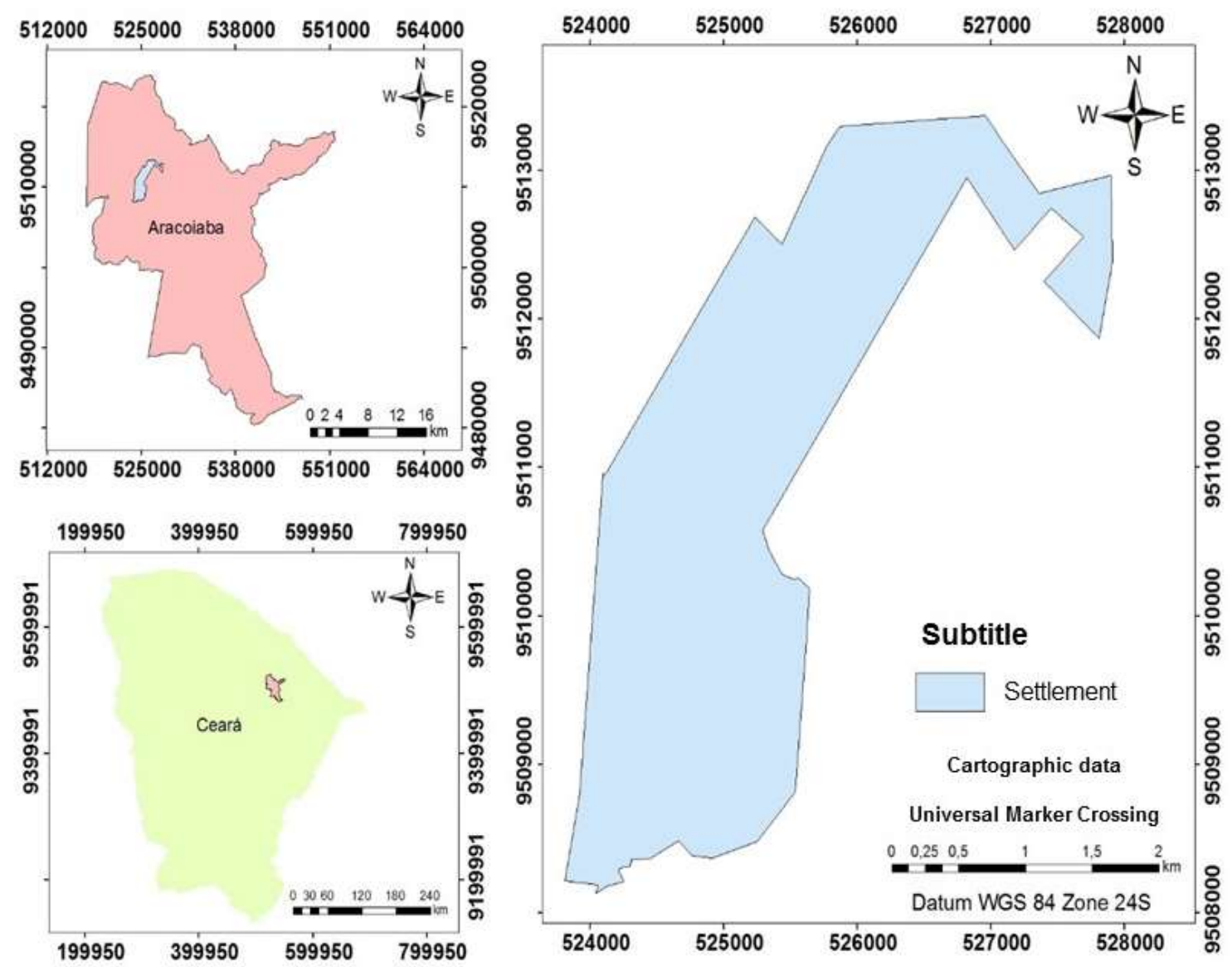

Source: Authors (2020).

\subsection{Methodological procedures used}

For the delimitation of the study area, he used image extracted from Google Earth Pro software. The manipulation and expression of geographic data were performed through the ArcMap 10.3 program. The identification of the cisterns was performed through in loco identification in the study area, the geographic location was obtained through the Global 
Positioning System (GPS), using as equipment the Garmim 76scx model receiver, UTM projection and Datum WGS84, spindle 24.

As part of the methodological instrument, a semi-structured questionnaire was applied in the community for quantitative and qualitative evaluation about storage, water use and ways of handling in cisterns. The questionnaire was applied in the morning in two parts, started in the community Pedra Aguda (southern portion of the settlement) and ended in Asunción (northern portion).

ANA (2011) carried out the procedures for collecting and storing water samples. All samples were collected in the morning between the months of June and July 2019. The physical-chemical analyses were determined in the general chemistry and microbiology laboratory of the University of International Integration of Afro-Brazilian Lusophony (UNILAB).

Six parameters were analyzed, temperature; which was measured at the time of collection, by a thermometer of mercury, turbidity; expressed by AP turbidimeter model 2000, pH-Potential Hydrogenic, Total Dissolved Solids (STD) and electrical conductivity (EC); they were measured by AZ - model 86505 conductivity bench equipment and apparent color; analyzed by photometry. The external temperature and humidity analyses in each cistern were estimated with the aid of a hygrometer term. All these collection materials are presented in Figure 2.

(Continue...) 
Figure 2 - Methodological procedures for the analysis of water in cisterns: materials used (A); water collection (B); laboratory analysis (C) and cisterns (D).
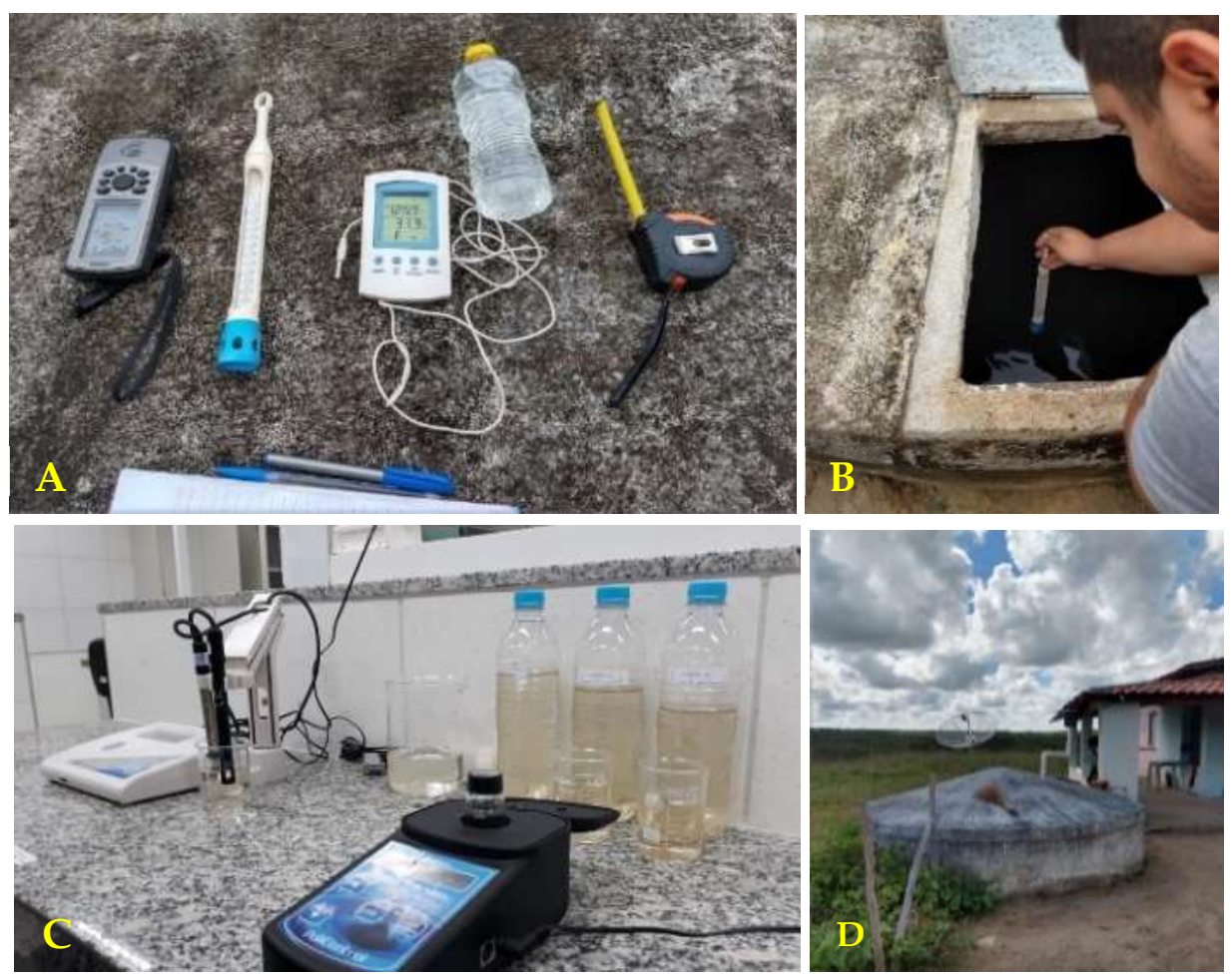

Source: Authors (2020).

\subsection{Descriptive statistics}

The data were analyzed by descriptive statistics with mean, median, minimum, maximum, variance, standard deviation and coefficient of variation. To classify the coefficient of variation CV (\%) of the parameters, we used the classification of Pimentel-Gomes (1985), in which the intervals are arranged at low (CV $\leq 10 \%)$; medium (10\% < CV $\leq 20 \%)$; high (20\% $<\mathrm{CV} \leq 30 \%)$; and very high (CV > 30\%). It should be noted that the coefficient of variation is the measure that determines how far a given attribute distances itself from the average percentage of the area evaluated, thus identifying that a possible irregularity may have occurred at the sampled point.

Pearson's linear correlation was used to verify the degree of relationship between the parameters studied through the Rubio statistical software (BHERING, 2017). 


\subsection{Multivariate statistics}

The multivariate statistics used in the study were grouping analysis and component analysis, two techniques of analysis of interdependence and relations between them in a set of variables (RESENDE, 2007). The evaluation of the techniques of grouping analysis and principal component analysis was used the Rbio statistical software (BHERING, 2017). The Euclidean distance and the hierarchical method of complete connection were used in the construction of the dendogram.

\section{Results and discussion}

\subsection{Characterization of tanks and discussion of the questionnaire}

Seventeen cisterns were mapped in the settlement, 12 belonging to the community of Asunción and 5 in the community of Pedra Aguda (Figure 3). The spatialization of the cisterns realized that the largest occupation is to the north of the settlement while the smallest is to the south. All the implanted cisterns have been identified as being in use.

Figure 3 - Spatial distribution of the cisterns of the Nova Assunção settlement.

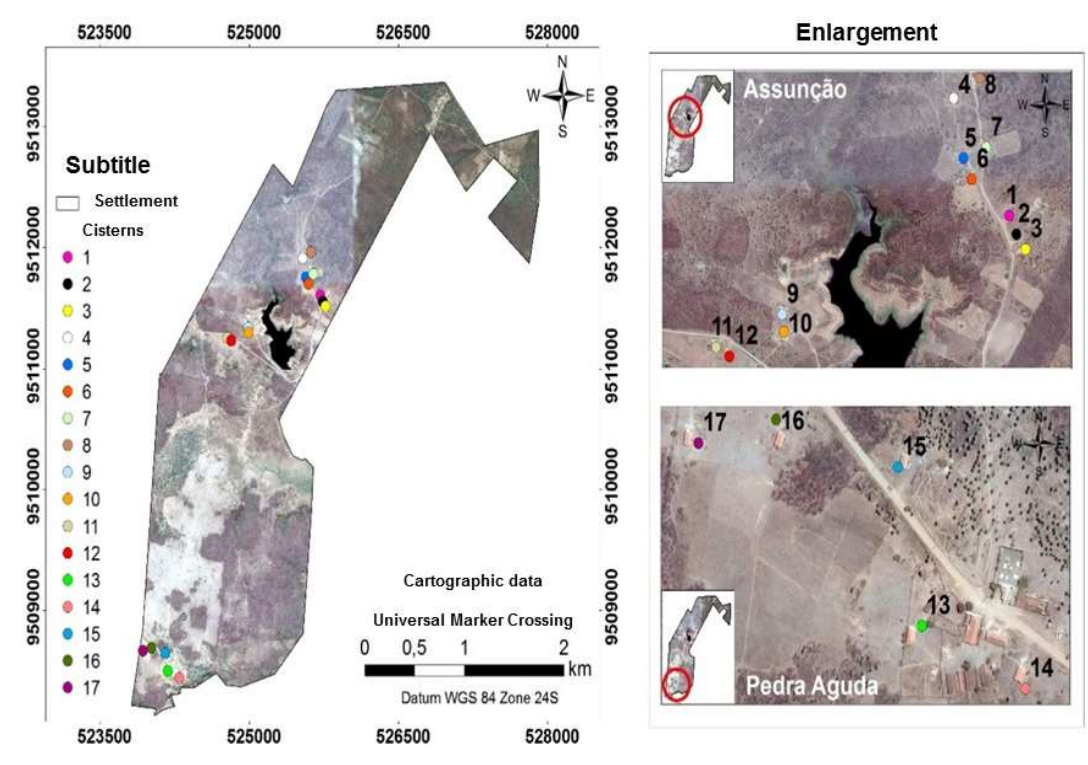

Source: Authors (2020). 
It was observed that the cisterns are located in very distinct areas of elevation and it was perceived that the variation between the minimum and maximum was 81 to $324 \mathrm{~m}$ (Table 1). It was noted that the water catchment areas also vary significantly; cistern 3 has only 9.7 $\mathrm{m}^{2}$ of area to capture rainwater, while cistern 14 has $153 \mathrm{~m}^{2}$.

This variation has made it understood why some cisterns fill up quickly, while others take practically the entire rainy season to reach maximum capacity. It was observed that tanks 2, 3 and 11 presented the smallest areas, as these do not take advantage of the maximum potential of the trough area of the residence.

For the destination of the stored water, it was found that $100 \%$ of the water in the cisterns is used for human consumption. Only cisterns 4, 8 and 10 presented a second destination, which consists in the use for domestic activities, which further promotes the need for analysis of the potability parameters of these waters.

It was identified that 13 cisterns (76.5\%) do not have any type of protection screen both in the water inlet and outlet area (Table 1). This fact becomes worrying because all these cisterns are very vulnerable to the various forms of water contamination. Screens are important barriers to protect against insects, plant debris, solid soil particles and household roof debris. In this way, the cisterns constitute an "open" system and are susceptible to the entrance of pollutants, making necessary the correct use and practical knowledge of their consumers about water quality ((PALHARES, 2016).

Table 1- Identification of cisterns and characterization of use.

\begin{tabular}{|c|c|c|c|c|c|c|}
\hline \multirow[t]{2}{*}{$\begin{array}{l}\text { Cisterns } \\
\text { sampled }\end{array}$} & \multicolumn{2}{|c|}{$\begin{array}{c}\text { Geographical } \\
\text { location } \\
\text { (UTM) }\end{array}$} & \multirow[t]{2}{*}{$\begin{array}{l}\text { Elevation } \\
(\mathbf{m})\end{array}$} & \multirow[t]{2}{*}{$\begin{array}{l}\text { Gutter: total } \\
\text { collection } \\
\text { area }\left(\mathbf{m}^{2}\right)\end{array}$} & \multirow[t]{2}{*}{$\begin{array}{l}\text { Type of } \\
\text { water } \\
\text { use }\end{array}$} & \multirow[t]{2}{*}{$\begin{array}{l}\text { Protecti } \\
\text { on } \\
\text { screen }\end{array}$} \\
\hline & $\begin{array}{c}\text { Longitud } \\
\mathrm{e}\end{array}$ & Latitude & & & & \\
\hline $\mathrm{N}^{\circ} 1$ & 525713 & 9511604 & 104 & 60 & A & Yes \\
\hline $\mathrm{N}^{\circ} 2$ & 525736 & 9511555 & 104 & 12,80 & $A$ & No \\
\hline $\mathrm{N}^{\circ} 3$ & 525765 & 9511516 & 103 & 9,75 & $A$ & No \\
\hline $\mathrm{N}^{\circ} 4$ & 525535 & 9511913 & 107 & 71,87 & $A-B$ & No \\
\hline$N^{\circ} 5$ & 525566 & 9511755 & 107 & 83,45 & $A$ & No \\
\hline$N^{\circ} 6$ & 525593 & 9511700 & 109 & 65,03 & $A$ & No \\
\hline$N^{\circ} 7$ & 525639 & 9511784 & 104 & 140,4 & A & No \\
\hline$N^{\circ} 8$ & 525618 & 9511966 & 108 & 63 & $A-B$ & No \\
\hline
\end{tabular}




\begin{tabular}{ccccccc}
$\mathrm{N}^{\circ} 9$ & 524986 & 9511343 & 120 & 54,4 & $\mathrm{~A}$ & No \\
$\mathrm{N}^{\circ} 10$ & 524991 & 9511298 & 106 & 60,58 & $\mathrm{~A}-\mathrm{B}$ & Yes \\
$\mathrm{N}^{\circ} 11$ & 524774 & 9511257 & 83 & 9,70 & $\mathrm{~A}$ & No \\
$\mathrm{N}^{\circ} 12$ & 524817 & 9511233 & 81 & 135,65 & $\mathrm{~A}$ & Yes \\
$\mathrm{N}^{\circ} 13$ & 524179 & 9508498 & 248 & 72,64 & $\mathrm{~A}$ & No \\
$\mathrm{N}^{\circ} 14$ & 524295 & 9508440 & 291 & 153 & $\mathrm{~A}$ & $\mathrm{No}$ \\
$\mathrm{N}^{\circ} 15$ & 524152 & 9508645 & 324 & 85 & $\mathrm{~A}$ & Yes \\
$\mathrm{N}^{\circ} 16$ & 524015 & 9508689 & 82 & 88,2 & $\mathrm{~A}$ & $\mathrm{No}$ \\
$\mathrm{N}^{\circ} 17$ & 523928 & 9508667 & 83 & 80.30 & $\mathrm{~A}$ & $\mathrm{No}$ \\
\hline
\end{tabular}

A: human consumption

B: household use

No matter how close the cisterns are, (if evaluated by community) it is necessary to observe climatological parameters such as temperature and humidity, since all of them are submitted to different modifications in the landscape. It was observed that the relative humidity of the air at the 17 collection points had greater variation than the temperature (Figure 4).

It was observed that the humidity had a range of 52 to $88 \%$ (Figure $4-A$ ). The temperature varied from 22 to $30^{\circ} \mathrm{C}$ (Figure 4 - B). It was observed that the cisterns with the highest external temperatures had no form of cover (protection) and no trees in the vicinity, being cisterns 11,12 and $15\left(29,29\right.$ and $30^{\circ} \mathrm{C}$, respectively). It is important to point out that the external temperature influences the temperature inside the cistern, which in turn influences the water temperature. According to Brazil (2015) water temperature interferes with fluoridation, $\mathrm{pH}$ change, disinfection, solubility and ionization of water coagulant substances.

(Continue...) 
Figure 4 - Reactive humidity (A) and air temperature (B) at water collection sites.
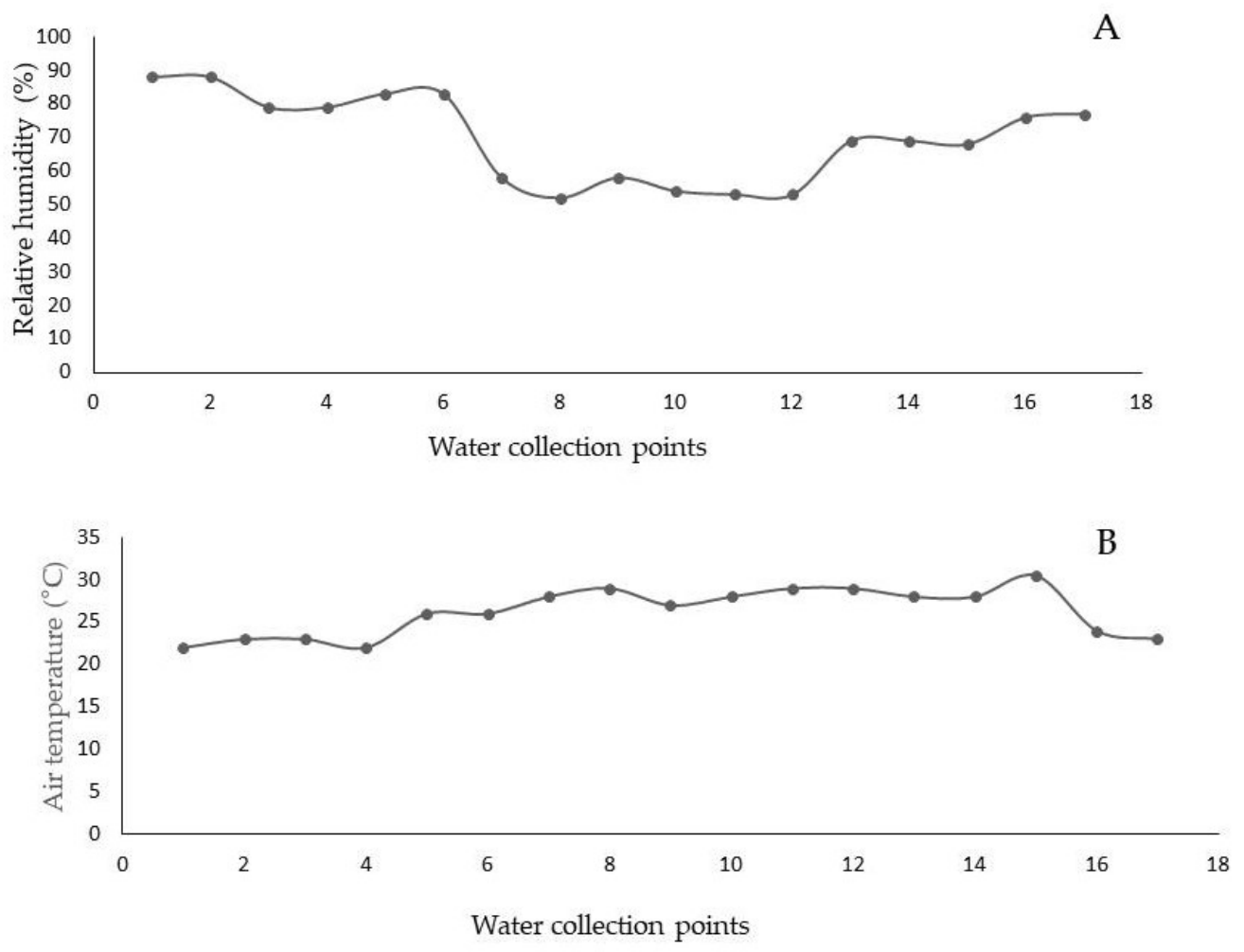

Source: Authors (2020).

\subsection{Physico-chemical analysis of water}

The water available in nature is not found in a pure form, since it is in constant use, being submitted to various forms of contamination, during its hydrological cycle, being the potential polluter of anthropic origin, mineral and/or organic materials (CARNEIRO, 2017). In this perspective, water intended for human consumption must undergo physical, chemical and biological analyses for the diagnosis of water quality and comparison with potability standards (RICHTER, 2011). There are several resolutions, manuals, ordinances and other documents available on the procedures of control and monitoring of water quality for human consumption. The STD were evaluated in accordance with Ordinance No. 2,914 (December 12, 2011). The electrical conductivity, color and turbidity, is based in Brazil (2006). The reference values for turbidity and $\mathrm{pH}$ are determined according to Brazil (2005).

Figure 5 shows the physical and chemical parameters analyzed in the water of the cisterns at the Nova Assunção settlement. It was observed that $35.3 \%$ (6) of the tanks 
presented an irregular apparent color with the relevant legislation. Identified irregularity in this attribute in tanks 4, 5, 6, 12, 14 and 17.

Figure 5 - Physical and chemical parameters analysed in the water of the cisterns at the Nova Assunção settlement: apparent color (A); electric conductivity (B); turbidity (C); temperature (D); STD-Total Dissolved Solids (E) e pH- Hydrogenionic Potential (F).
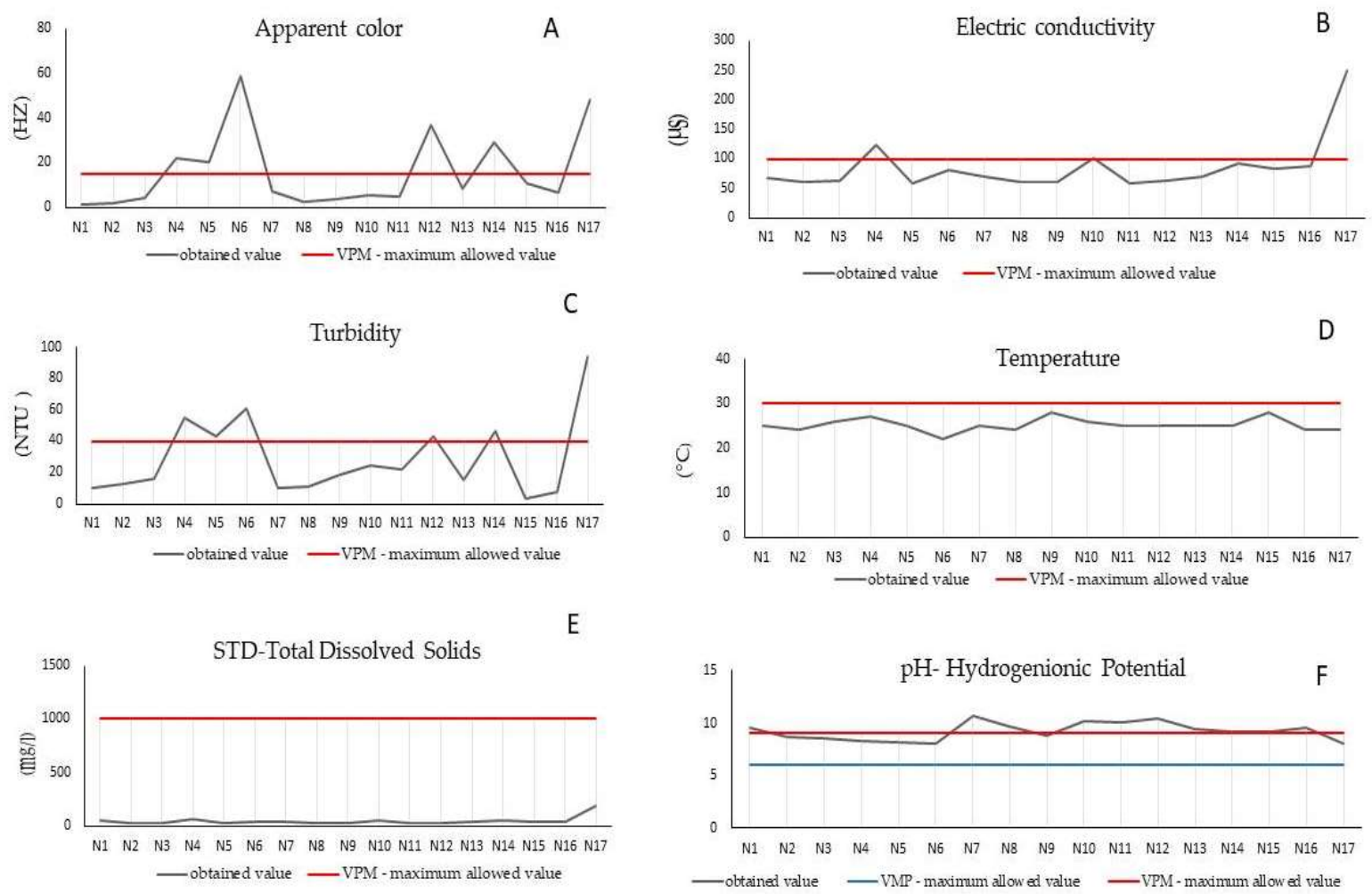

Source: Authors (2020).

For Funasa (2013) the color of the water comes from organic matter such as humic substances, tannins, and metals such as iron and manganese. According to Carneiro (2017) for the color of the water to be apparent, it must have an organic and mineral origin in the colloidal state or suspension. Therefore, it is believed that such changes may be caused to the detriment of organic material in the water since in some cisterns the presence of plant debris has been observed. It should be noted that color is one of the patterns that can be observed visual inadequacies, that aesthetically make consumption impossible, and that analyzed together with other parameters can identify potential for contamination. 
The analysis of electrical conductivity indicated that cisterns number 17, 04 and 10 showed results above the maximum allowed (250, 124 and $101 \mu \mathrm{s}$, respectively). This parameter determines the ability of water to transmit electrical current through dissolved substances. Thus, the high ionic concentration in water will provide greater conduction (BRAZIL, 2006). Thus, it is observed that conductivity is a parameter that correlates directly with total dissolved solids (ARAÚJO; OLIVEIRA, 2013).

As total solids in water increase, so does electrical conduction by these solids. This behavior can be observed because the cisterns that presented EC above the standard also presented the highest STD values. For the turbidity parameter, it was observed that the highest results, consequently the values in non-conformity with the legislation, were found in tanks $17,6,4,14$ and 5 . Turbidity is the degree of attenuation that a light beam suffers when passing through the water due to the presence of particulate matter in suspension (CETESB, 2009).

Turbidity is associated with the presence of solid debris that is suspended or deposited inside the tanks. The turbid waters in the cisterns may be the result of particles of sand, silt, clay and rock fragments, which are carried by precipitation.

For Oliveira (2016), one of the strategies to avoid this contamination is the disposal of the first rainwater. Another factor that can increase the presence of these particles in the water and, consequently, increase the level of turbidity, is the absence of protection screens and rainwater filtration, as can be seen in cisterns that obtained turbidity results above the allowed, all do not have this protection system. Among the cisterns that have protection, only one had a slight change, which can be associated with the interaction of other attributes.

The water temperature of the cisterns behaved uniformly, it was identified that none of the cisterns presented values above acceptable $\left(30^{\circ} \mathrm{C}\right)$. Tanks 9 and 15 had the highest values, both at $28^{\circ} \mathrm{C}$. In agreement with Matic et al. (2013) temperature is an attribute that measures the intensity of heat, thus reflecting the degree of heating of water and solar radiation in a given resource. The water temperature is an important factor in the water context since under appropriate conditions it guarantees the survival of microorganisms essential to water quality. 
The analysis of the attribute Total Dissolved Solids showed that $100 \%$ of the cisterns comply with the maximum permitted value $(1000 \mathrm{mg} / \mathrm{L})$. It was observed that the highest value corresponds to cistern $17(184 \mathrm{mg} / \mathrm{L})$ and the lowest to cistern $11(29 \mathrm{mg} / \mathrm{L})$. The increase of this attribute in the water is directly related to the forms of management in cisterns since this parameter indicates in quantitative terms the presence of solid macro and microparticles in the water. These particles can be deposited in the cisterns at the time of rainfall capitation or at the time of water collection using utensils, without the use of the pump. Another factor that can contribute to the accumulation of these particles is the internal cleaning performed over long periods.

It was possible to identify that approximately $65 \%$ of the cisterns evaluated showed non-conformity with the legislation, for the chemical potential attribute hydrogen ionic. It should be noted that this high number of cisterns with results above VMP expresses an alert condition, since this parameter is essential to the standards of potability, and its alteration may make human consumption and the usefulness for other purposes impossible. $\mathrm{pH}$ is a parameter indicating the degree of acidity or alkalinity of the medium (VASCONCELOS et al., 2013). According to Funasa (2013), the pH scale varies from 0 to 14, values below 7 determine acidic waters, above 7 determines alkaline waters and the value 7 expresses neutral $\mathrm{pH}$. Thus, it was noted that $100 \%$ of the waters analyzed were classified as alkaline waters, where the highest value was from cistern 12 , with a pH of 10.45. Thus, the reduction of this alkalinity can be achieved by adding neutralizing substances to the water.

The mean values indicated that the attributes of apparent color and $\mathrm{pH}$, showed greater changes, and consequently disagreement with VMP (15 Hz and 6 to 9, respectively). It was observed that the average variation of these attributes presented irregularity with that established by Brazilian legislation and/or entities of control and surveillance of water quality. This series indicates that there were changes in these attributes in most collection points, which characterizes the average spatialization of all attributes in the study area. It was identified that the other parameters presented an average variation within the allowed pattern (Table 2).

The dispersion variables analyzed to determine the variation of each collection point about the average of the physicochemical attribute. Thus, these points with greater 
variations should be observed and analyzed with greater attention because external agents (such as pollutants from the wrong handling of tanks) can contribute to the variability of these values, thus contributing to the dispersion of water quality standards (Table 2).

Thus, a low CV (\%) was observed for the temperature and $\mathrm{pH}$ parameters respectively (5.76 and $8.37 \%$ ). Thus, it was possible to notice that a low variability in the respective attributes occurred, demonstrating a homogeneity in all the cisterns analyzed. Electrical conductivity presented a high variation (23.47\%), indicating that more than half of the cisterns presented significant differences from the average value. For STD attributes, turbidity, and apparent color, the variation was classified as very high, i.e., a large number of cisterns showed a deviation from the average standard. This may be related to the forms of water handling in these cisterns, since these three attributes are influenced (altered or not) by particulate materials, which he observed at various collection points.

Table 2 - Physical-chemical attributes analyzed.

\begin{tabular}{|c|c|c|c|c|c|c|}
\hline \multirow{2}{*}{$\begin{array}{l}\text { Dispersio } \\
\mathbf{n} \\
\text { measures }\end{array}$} & \multicolumn{6}{|c|}{ Physical-Chemical Attributes } \\
\hline & $\begin{array}{l}\text { Apparent } \\
\text { color }(\mathrm{Hz})\end{array}$ & $\begin{array}{l}\text { EC } \\
(\mu s)\end{array}$ & $\begin{array}{l}\text { Turbidity } \\
\text { (NTU) }\end{array}$ & $\begin{array}{c}\text { Temperatur } \\
\text { e } \\
\left({ }^{\circ} \mathrm{C}\right)\end{array}$ & $\begin{array}{l}\text { STD } \\
(\mathrm{Mg} / \mathrm{L})\end{array}$ & pH \\
\hline Average & 15,96 & 85,58 & 29,11 & 25,17 & 46,96 & 9,19 \\
\hline Average & 7,30 & 70 & 19 & 25 & 35,50 & 9,16 \\
\hline Minimum & 1,50 & 59 & 03 & 22 & 29 & 8 \\
\hline Maximum & 59 & 250 & 94 & 28 & 184 & 10,70 \\
\hline Variance & 289,78 & 403,80 & 534,91 & 2,13 & 1256,17 & 0,59 \\
\hline $\mathrm{S}^{*}$ & 17,02 & 20,09 & 23,12 & 1,45 & 35,44 & 0,77 \\
\hline $\mathrm{CV}(\%)^{*}$ & 106 & 23,47 & 79,42 & 5,76 & 70,93 & 8,37 \\
\hline
\end{tabular}

According to Figure 6, it was observed that tanks 4, 12, 14 and 17 presented the greatest changes among the physical-chemical patterns; it was identified in all, 50\% of irregularity in the attributes. Cisterns 4 and 12 belong to the community of Asunción, while cisterns 14 and 17 are located on the Pedra Aguda. Then the cisterns 5, 6 and 10 were kept with $33 \%$ of the parameters above the maximum allowed value, all located in the community 
of Asunción. Thus, it is important to point out that among the settlement's cisterns, the ones pointed out here (Figure 6) need a more critical look, with the implementation of use techniques (to reduce contamination) and water treatment through the specificities of each altered attribute.

Figure 6 - Cisterns with major changes in the evaluated parameters.

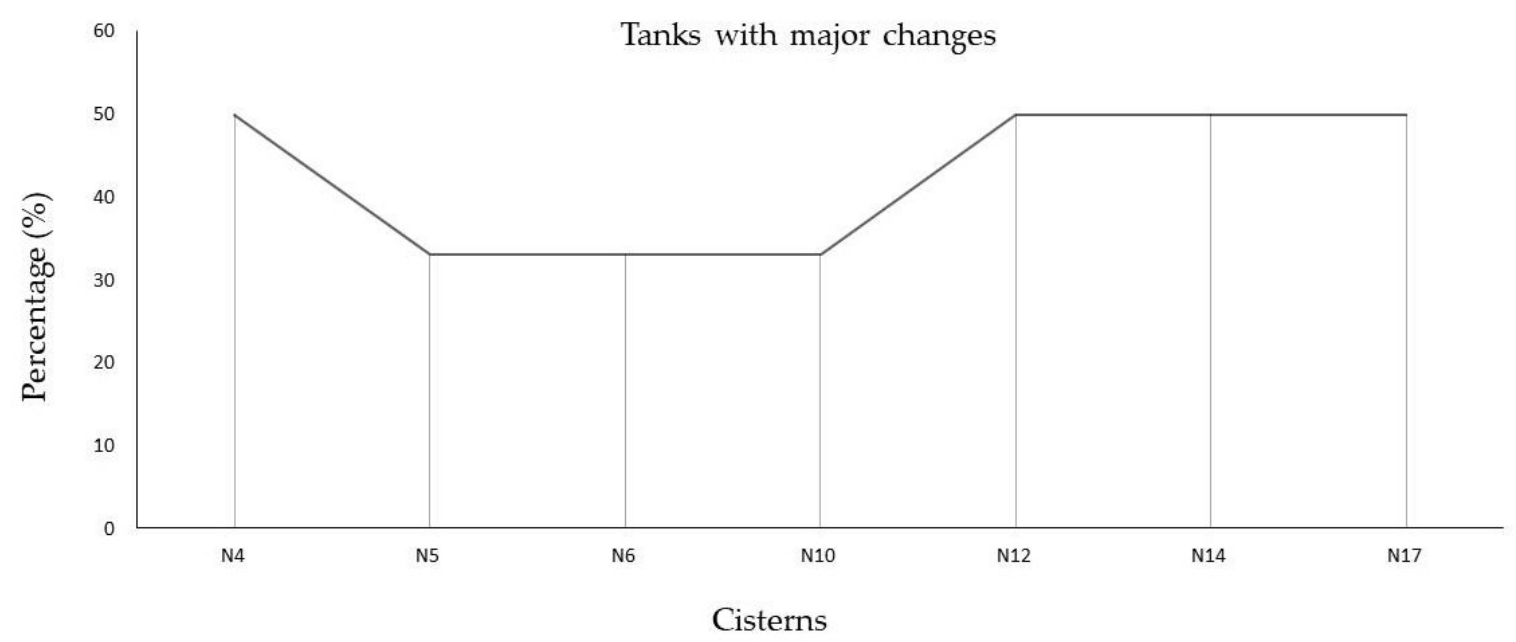

Source: Authors (2020).

\subsection{Correlation and multivariate analyzes}

The correlation analysis between cistern water quality parameters identifies correlated pairs. The correlations between $\mathrm{pH}, \mathrm{EC}, \mathrm{STD}$, colour, turbidity and water temperature are shown in table 3 . The pairs $\mathrm{pH} \times$ Turbidity $\left(r=-0.5247^{*}\right)$, EC $\times$ Color $(r=0.5221)$ were significant at $5 \%$ probability by the t-test. Negative correlation values express increase in one variable and decrease in the other. Already significant at $1 \%$ by $t$-test were EC $\times$ STD pairs $(r=0.9849)$, EC $\times$ Turbidity $(r=0.7427)$. The correlation between the pairs $p H \times E C(r=-0.3748$ with $p=$ 0.1382), i.e., not significant, similar answer was found by Girão et al. (2007). Bertossi et al. (2013), studying water quality indicators, found a high correlation between EC x STD $(r=0.856)$. 
Table 3 - Correlation matrix between 6 cistern water quality parameters.

\begin{tabular}{|c|c|c|c|c|c|c|}
\hline Variables & $\mathrm{pH}$ & EC & STD & Color & Turbidity & Temperature \\
\hline $\mathrm{pH}$ & 1 & $\begin{array}{c}-0.3748 \\
p=0.1382\end{array}$ & $\begin{array}{c}-0.3732 \\
p=0.140 \\
0\end{array}$ & $\begin{array}{c}-0.4201 \\
p=0.0931\end{array}$ & $\begin{array}{c}- \\
0.5247^{*} \\
p= \\
0.0305\end{array}$ & $\begin{array}{c}0.0664 \\
p=0.80 \\
01\end{array}$ \\
\hline EC & $\begin{array}{c}-0.3748 \\
p=0.1382\end{array}$ & 1 & $\begin{array}{c}0.9849^{* *} \\
p=7.4 \times 10 \\
-13\end{array}$ & $\begin{array}{r}0.5221^{*} \\
p=0.0315\end{array}$ & $\begin{array}{l}0.7427^{\star *} \\
p=0.0006\end{array}$ & $\begin{array}{l}-0.1062 \\
p=0.6850\end{array}$ \\
\hline STD & $\begin{array}{c}-0.3732 \\
p=0.1400\end{array}$ & $\begin{array}{c}0.9849 * * \\
p=7.4 \times 10^{-} \\
13\end{array}$ & 1 & $\begin{array}{c}0.4987^{*} \\
p=0.0415\end{array}$ & $\begin{array}{c}0.7223^{* *} \\
p=0.0010\end{array}$ & $\begin{array}{l}-0.1470 \\
p=0.5732\end{array}$ \\
\hline Color & $\begin{array}{c}-0.4201 \\
p=0.0931\end{array}$ & $\begin{array}{c}0.5221^{*} \\
p=0.0315\end{array}$ & $\begin{array}{c}0.4987^{*} \\
p=0.0415\end{array}$ & 1 & $\begin{array}{c}0.8662^{\star *} \\
p=6.9 \times 10 \\
-6\end{array}$ & $\begin{array}{r}-0.4399 \\
p=0.077\end{array}$ \\
\hline Turbidity & $\begin{array}{c}-0.5247^{*} \\
p=0.0305\end{array}$ & $\begin{array}{l}0.7427^{* *} \\
p=0.0006\end{array}$ & $\begin{array}{l}0.7223^{* *} \\
p=0.0010\end{array}$ & $\begin{array}{l}0.8662^{\star *} \\
p=6.9 \times 0 \\
-6\end{array}$ & 1 & $\begin{array}{l}-0.3032 \\
p=0.2367\end{array}$ \\
\hline $\begin{array}{c}\text { Temperatur } \\
\mathrm{e}\end{array}$ & $\begin{array}{c}0.0664 \\
p=0.800 \\
1\end{array}$ & $\begin{array}{c}-0.1062 \\
p=0.6850\end{array}$ & $\begin{array}{c}-0.1470 \\
p=0.5732\end{array}$ & $\begin{array}{r}-0.4399 \\
p=0.077\end{array}$ & $\begin{array}{c}-0.3032 \\
p=0.2367\end{array}$ & 1 \\
\hline
\end{tabular}

Significant at $5 \%\left({ }^{\star}\right)$ level and significant at $1 \%\left({ }^{* *}\right)$ level by the t-test.

In the dendrogram (Figure 7), 6 groups were detected, identified below: Group 1, consisting of samples 1, 2, 3, 7, 8, 9, 11, 13, 15 and 16; Group 2, sample 5 and 12; Group 3, sample 4; Group 4, consisting of samples 10 and 14; Group 5, consisting of sample 6 and Group 6, consisting of sample 17. Group 1 presented the greatest similarities between the sampled points, considering the water quality parameters of the cisterns. The co-phenetic correlation coefficient (Figure 8) determined in this grouping was high $(r=0.9645)$. In a study by Crispim et al (2019), the estimated cofenetic correlation coefficient was $r=0.81$, making possible inferences with visual analysis of the dendrogram. Sokal and Rohlf (1962) reported that high values of coefficients express less distortion of the original data, resulting in a better grouping. 
Figure 7 - Dendrogram estimated in the grouping analysis, using the Euclidean distance by the Hierarchical Full Link method. Coefficient of cofenetic correlation was equal to 0.9645 .

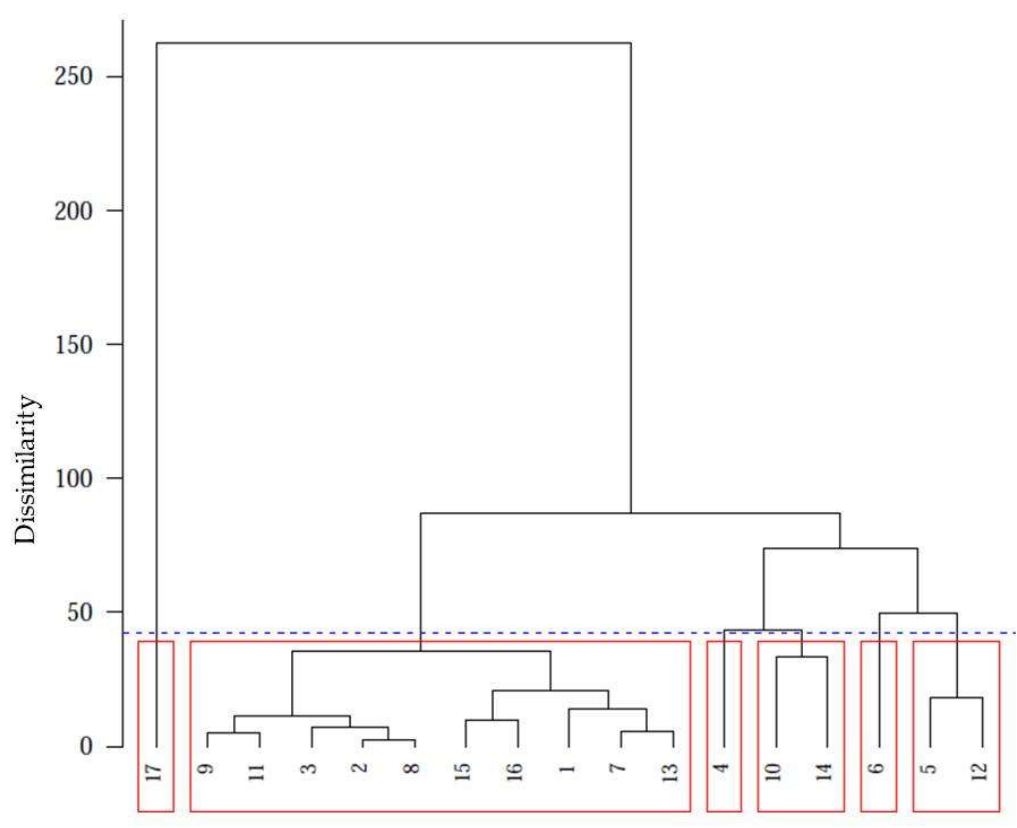

Source: Authors (2020).

In order to carry out the analysis of the main components, six quality parameters of cistern water were studied, i.e., there was a reduction of dimension six, in two main components. In interpretation of the biplot, it is verified that the total variance of the data was $77.72 \%$, being concentrated in two dimensions, the first and the second main components, respectively with 59.36 and $18.36 \%$ (Figure 8). The results verified in the cistern water quality study corroborate from Girão et al. (2007) that had total variance of the data $81.33 \%$, considering the first and second main components. Souza et al. (2013) evaluating water quality with multivariate technique of principal component analysis, found the total variance of $89.9 \%$, being derived from the sum of three components.

(Continue...) 
Figure 8 - Biplot Comp.1 x Comp.2 of the water quality parameters of cisterns.

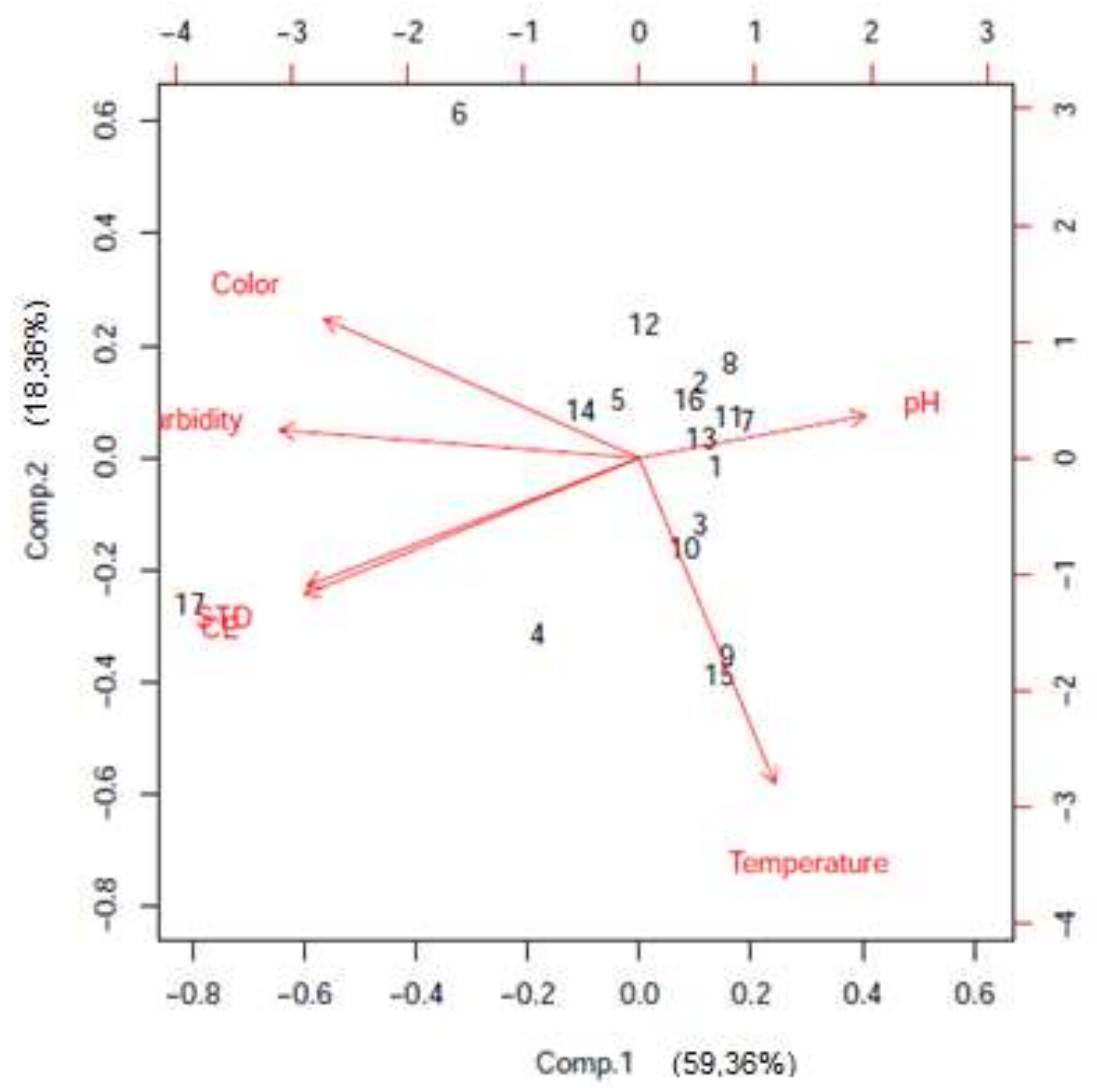

Source: Authors (2020).

The first main component is given by $\mathrm{Z} 1=0.314 \mathrm{pH}-0.464$ CE-0.460STD-0.436Cor0.498 Turbidity +0.188 Temperature. The loads for $\mathrm{pH}$ and temperature were positive, while the loads for EC, STD, Color and turbidity were negative. These values express the relative importance of each variable in relation to the main component; the positives express direct relationship, while the negatives are inversely proportional. The EC and STD variables presented similar contribution in the main component 1 . The $\mathrm{pH}$ and temperature were the variables that presented the greatest contribution to the main component 1.

\section{Conclusion}

The attributes apparent color, EC, turbidity and $\mathrm{pH}$ show patterns of inadequacy to consumption patterns. It should be noted that water in cisterns is the only water source used to meet the basic consumption needs of settlement people, such as cooking food, drinking, 
and personal hygiene. Other analyses (physical, chemical and biological) are necessary for a more complete diagnosis about the quality of the water used by the community.

The main component analysis selected two components of cistern water quality in the Nova Assunção Settlement, explaining $77.72 \%$ of the total variance.

The coefficients of the cophenetic correlation of $r=0.9645$ suggested good dendrogram quality estimated considering the water quality parameters evaluated in the study.

The mapped cisterns are an indispensable alternative for the storage and guarantee of water in the community. However, it is necessary to adopt some practices of correct use to ensure the quality of this good.

\section{References}

ARAUJO, M. C. de; OLIVEIRA, M. B M. de. Monitoring water quality in a stream at the Federal University of Pernambuco, Brazil. Ambiente \& Água, v. 8, n. 3, p. 247-257, 2013.

ASA - Articulation of the Semiarid Region. Training and Social Mobilization Program for Living with the Semi-Arid: One Million Rural Cisterns. Annex II to the FEBRABAN and AP1MC Technical and Financial Cooperation Agreement, 2003.

BERTOSSI, A. P. A.; MENEZES, J. P. C.; CECÍlIO, R. A.; GARCIA, G. O.; NEVES, M. A.. Selection and grouping of water quality indicators using Multivariate Statistics. Semina: Agricultural Sciences, Londrina, v. 34, n. 5, p. 2025-2036, set./out. 2013. DOI: 10.5433 / 16790359.2013v34n5p2025. https://www.redalyc.org/comocitar.oa?id=445744135003. Accessed on: Feb 14, 2020.

BHERING. L. L. Rbio: A tool for biometric and statistical analysis using the R platform. Crop Breeding and Applied Biotechnology, v.17, n.2, p. 187-190, 2017. Available at: <http://www.biometria.ufv.br/wp-content/uploads/ArtigoRbio2017-CBAB.pdf>. Accessed on: Feb. 13, 2020.

BRAZIL: National Water Agency - ANA, 2011. National sample collection and preservation guide, 2011. chap.3, p.51-56. Available at: http://arquivos.ana.gov.br/institucional/sge/CEDOC/Catalogo/2012/GuiaNacionalDeColeta .pdf. Accessed on: Dec. 05, 2019.

BRAZIL. National Water Agency - ANA. Ordinance No. 149, of March 26, 2015. Available at: http://arquivos.ana.gov.br/imprensa/noticias/20150406034300_Portaria_149-2015.pdf. Accessed on: Nov. 23, 2019. 
BRAZIL: Ministry of Health. Provides for the control and surveillance procedures of the quality of water for human consumption and its standard of potability. Ordinance

2,914, of December 12.2011 .2 Available at: <http://site.sabesp.com.br/site/uploads/file/asabesp_doctos/PortariaMS291412122011.pdf >, Accessed on: Feb. 12, 2020.

BRAZIL: Secretariat of Health Surveillance. Surveillance and quality control of water for human consumption. 212 p. Brasília: Ministério da Saúde, 2006. Available at: <http://bvsms.saude.gov.br/bvs/publicacoes/vigilancia_controle_qualidade_agua.pdf>, Accessed on: Nov. 23, 2019.

BRAZIL: National Council for the Environment-CONAMA. Resolution No. 357, of March 17, 2005. Available at: <http://www2.mma.gov.br/port/conama/legiabre.cfm?codlegi=459>. Accessed on: Sep. 22, 2019.

CONTI, I. L.; SCHROEDER, E. O. Strategies for Living with the Brazilian Semiarid: Texts and Articles by Participating Students. Support Foundation of the Federal University of Rio Grande do Sul - FAURGS / REDEgenteSAN / Brazilian Institute of Development and Sustainability - IABS / Spanish Agency for International Cooperation for Development AECID / Ministry of Social Development and Fight against Hunger - MDS / Editora IABS, Brasília-DF, Brazil - 2013, 208p. Available at: <http://platform.redesan.ufrgs.br/biblioteca/pdf_bib.php?\%20COD_ARQUIVO=17908> , Accessed on: Feb. 12, 2020.

CARNEIRO, F. J. B. Mapping the use of pesticides and the quality of spring water in the rural community of Piroás, Redenção - CE. 2016. 78f. Monograph (Specialization) Agronomy Course, University of International Integration of Afro-Brazilian Lusophony, Redenção, 2016.

CETESB - Environmental Sanitation Technology Company. Inland Water Quality in the State of São Paulo. Reporting Series. Appendix A - Environmental and Health Significance of Water and Sediment Quality Variables and Analytical and Sampling Methodologies, p.1920, 2009.

CRISPIM, D. L.; FERNANDES, L. L.; ALBUQUERQUE, R. L. O. Application of multivariate statistical technique on sustainability indicators in the municipalities of Marajó-PA. Principia - IFPB Scientific and Technological Dissemination, João Pessoa, n. 46, p. 145-154, set. 2019. Available at: <https://periodicos.ifpb.edu.br/index.php/principia/article/view/3203>. Accessed on: Feb. 14, 2020.

FUNASA - National Health Foundation. Practical water analysis manual. 4. ed. - Brasília: Funasa, 2013. 150p. Available at: <http://www.funasa.gov.br/site/wpcontent/files_mf/manual_pratico_de_analise_de_agua_2. pdf>. Access on: Nov 15, 2019.

GIRÃO, E. G.; ANDRADE, E. M.; ROSA, M. F.; ARAÚJO, L. F. P.; MEIRELES, A. C. M. Selection of 
water quality indicators in the Jaibaras River using the analysis of the main component. Ciência Agronômica, v.38, n.1, p.17-24, 2007. Available at: http://ccarevista.ufc.br/seer/index.php/ccarevista/article/view/144/139. Accessed on: Feb. $14,2020$.

IPECE - Economic Research and Strategy Institute of Ceará. Municipal Profile 2017 Aracoiaba. Available at: https://www.ipece.ce.gov.br/perfil-municipal-2017/. Accessed on: Sep. 23, 2019.

LORDELO, L. M. K.; PORSANI, J. M.; BORJA, P. C. Physical-chemical quality of water for human supply in municipalities in the hinterland of Bahia: a study considering several sources of supply. Groundwater, v.32, n.1, p.97-105, 2018. Lepidus Tecnologia. http://dx.doi.org/10.14295/ras.v32i1.28896. Available at: <https://aguassubterraneas.abas.org/asubterraneas/article/view/28896>. Accessed on: Nov. 24, 2019.

MAIA, A. K. A .; SALLES, M. G. F .; PINTO, C. M ;; RODRIGUES, I. C. S ;; VIANA NETO, A. M. The implantation of dairy goats in the Nova Assunção Settlement, Aracoiaba - CE. Agrarian Academy, Goiânia, v.6, n.11, p.1-14, 2019. Available at: <http://www.conhecer.org.br/Agrarian\%20Academy/2019A/a\%20implantacao.pdf>. Accessed on: Fev. 14, 2020.

MATIC, N ; MIKLAVCIC, I ; MALDINI, K ; DAMIR, T ; CUCULIC, V ; CARDELLINI, C. et al. Geochemical and isotopic characteristics of karstic springs in coastal mountains (Southern Croatia). Journal of Geochemical Exploration, n.132, p. 90-110, 2013.

MARENGO, J. A. Global climate change and its effects on biodiversity: characterization of the current climate and definition of climate change for the Brazilian territory throughout the 21st century. Brasília, DF: MMA, 2006. 202 p. il. (Biodiversity, 26).

PALÁCIO, H. A. Q ;ANDRADE, E. M ; LOPES, F. B ; ALEXANDRE, D. M. B ; ARRAES, F. D. D. Similarity in the quality of surface water in the Curu basin, Ceará. Ciência Rural, Santa Maria, v.39, n.9, p.2494-2500, Dec, 2009 Available at: http://www.scielo.br/pdf/cr/v39n9/a417cr1528.pdf. Accessed on Feb. 14, 2020.

OLIVEIRA, J. C. A. L. Qualitative Analysis of Pollutants in Rainwater in Different Scenarios in the Pernambucan Semiarid: Urban Zone, Rural Zone and Industrial Area, 111f. 2016. Dissertation (Master) - Federal University of Pernambuco, 2016.

PALHARES, J. C. P. Rainwater harvesting and storage in cisterns for use in animal production, Embrapa Pecuária Sudeste (Documents, n.122), 2016, 32p. Available at: <https://www.infoteca.cnptia.embrapa.br/infoteca/bitstream/doc/1050541/1/documentos 1 22.pdf>, accessed at: Accessed on: Feb. 12, 2020.

PIMENTEL-GOMES, F. Course in Experimental Statistics. 12. ed. Piracicaba: Livelaria Nobel, 1985. 467p. 
RICHTER, C. A. Water: treatment methods and technologies. P. 65-81. São Paulo: Blucher, 2011.

SALGADO, E. V.; ANDRADE, E. M.; FONTENELE, S. B.; MEIRELES, A. C. M. SIMILARITY OF HYDROCHEMICAL VARIABLES WITH THE USE OF MULTIVARIATED ANALYSIS, IN THE SALGADO BASIN, CEARÁ. Revista Caatinga, v.24, n.3, p.158-166, 2011. Available at: https://www.redalyc.org/pdf/2371/237119874021.pdf. Accessed on: Feb. 14, 2020.

SILVA, C. V. Quality of rainwater for human consumption stored in plate cisterns. Case study: Araçuaí, MG. 2006. 2006. Dissertation (Master in Sanitation, Environment and Water Resources) - Engineering School of the Federal University of Minas Gerais, Minas Gerais-MG.

SILVA, José Adailton et al. Water management from plate cisterns: socio-environmental assessment of P1MC efficiency in the municipality of Pedra Lavrada-PB. Holos, [s.l.], v. 4, p.47-60, 2 aug. 2014. Available at: <https://www.redalyc.org/pdf/4815/481547173006.pdf>. Accessed on: Nov. 24, 2019.

SOKAL, R. R, ROHLF, F. J. The comparison of dendrograms by objective methods. Taxon, v.11, n.2, p.33-40, $1962 . \quad$ Available at: $<$ https://www.researchgate.net/publication/232128980_Sokal_RR_Rohlf_FJ_The_compariso n_of_dendrograms_by_objective_methods_Taxon_11_33-40> Accessed on: Feb 132020.

SOUZA, A ; FONTENELE, S. B ; OLIVEIRA, A. P. G ; LASTORIA, G ; GABAS, S ; DIAS, C. Similarity in the quality of surface water in the Rio Negro basin, MS. Magazine of the Center for Natural and Exact Sciences. v.35 n.2, p.176-189, 2013. Available at: <https://periodicos.ufsm.br/cienciaenatura/article/view/12571/7982>. Accessed on: Feb 14 2020.

TAVARES, A. C. Physical, chemical and microbiological aspects of water stored in cisterns in rural communities in the semi-arid region of Paraíba. 2009. 166f. 2009. Dissertation (Master in Development and Environment) - Federal University of Paraíba / State University of Paraíba. Campina Grande - PB.

VASCONCELOS, N. S.; DANTAS NETO, J.; MEDEIROS, J. F.; C. LIMA, J. G. S. Groundwater quality in the irrigated area of the Pau Branco community in Mossoró (RN). Holos, v.1, n.29, p.4765, 2013. Available at: <http://www2.ifrn.edu.br/ojs/index.php/HOLOS/article/view/1271/637>, Accessed on: Feb 162020. 